Periodontitis ve tip 2 diyabetli bireylerdeki glisemik kontrolün salya antimikrobiyal peptid seviyesine olan etkisinin incelenmesi

\section{The effect of glycemic control on salivary antimicrobial peptide levels in patients with periodontitis and type 2 diabetes mellitus}

\section{Dr. Öğr. Ü. Doğukan Yılmaz}

Sakarya Üniversitesi, Diş Hekimliği Fakültesi,

Periodontoloji A.D., Sakarya

Orcid ID: 0000-0003-2576-0885

Dr. Dt. Ali Orkun Topçu

Özel Klinik, Periodontoloji Uzmanı, Ankara

Orcid ID: 0000-0002-0930-0013

Dr. Emine Ülkü Akçay

Sakarya Üniversitesi, Tıp Fakültesi,

İç Hastalıkları A.D., Sakarya

Orcid ID: 0000-0002-5337-8838

Prof. Dr. Ali Tamer

Sakarya Üniversitesi, Tıp Fakültesi,

İç Hastalıkları A.D., Sakarya

Orcid ID: 0000-0003-2005-0737

Prof. Dr. Mustafa Altındiş

Sakarya Üniversitesi, Tıp Fakültesi,

Tibbi Mikrobiyoloji A.D., Sakarya

Orcid ID: 0000-0003-0411-9669

Geliş tarihi: 02 Temmuz 2019

Kabul tarihi: 09 Ocak 2020

doi: 10.5505/yeditepe.2020.58070

\section{Yazışma adresi:}

Dr. Öğr. Üye. Doğukan Yılmaz

Sakarya Üniversitesi Diş Hekimliği Fakültesi,

Periodontoloji A.D

Adnan Menderes Bulvarı 122/B Adapazarı/Sakarya

Tel: 02642406327

E-posta: dogukanyilmaz@sakarya.edu.tr

\section{ÖZET}

Amaç: Insan beta-defensinler (hBD) ve kathelisin (LL-37) homeostazın sağlanmasında önemli ve çoklu görevler alırlar. Oral ve periodontal doku ve sıvilarda, Tip 2 Diabetes Mellitus (T2DM) ile bu peptidler arasındaki ilişki net değildir. Çalışmamızın amacı, T2DM'li bireylerde glisemik kontrol seviyesinin, salya hBD ve LL-37 konsantrasyonu üzerine olan etkisinin incelenmesidir.

Gereç ve Yöntem: Çalışmaya 178 birey dahil edilmiştir. Demografik veriler, dental ve medikal geçmişler sözlü olarak elde edilmiştir. Glisemik kontrol seviyeleri için açlık kan şekeri ve glikolize hemoglobin (HbA1c) değerleri ölçülmüştür. Tüm ağız periodontal indeks değerleri ölçülerek panaromik filmler yardımıyla periodontal teşhisler yapılmıştır. Bireylerden stimüle olmayan yöntemle salya örnekleri toplanmış ve ELISA tekniği ile salya hBD -1, -2, -3, LL-37 ve ileri glikolizasyon son ürünü (AGE) değerleri ölçülmüştür.

Bulgular: Dişeti sağlıklı bireylerden oluşan gruplar arasında ve kontrollü T2DM bireylerin salya hBD seviyelerinin diğer gruplara oranla anlamlı derecede yüksek olduğu tespit edilmiştir. $(p<0.001)$ Periodontitisli ve kontrollü T2DM'li bireylerin salya $\mathrm{hBD}$ seviyelerinin ise; diğer periodontitisli gruplara göre anlamlı derecede düşük olduğu tespit edilmiştir. $(p<0.001)$. Salya LL-37 değerleri incelendiğinde ise; hem dişeti sağlıklı hem de periodontitisli bireylerden oluşan gruplarda, kontrolsüz T2DM'li bireylerden oluşan gruplarda en yüksek olduğu tespit edilmiştir. ( $p<0.001, p<0.001$, sırasıyla) Korelasyon analizlerine göre, periodontitisli ve kontrollü T2DM'li bireylerin salya hBD-1, $-2,-3$ değerleri salya AGE miktarı ile negatif korelasyon gösterirken $(r=-0.411 p=0.020, r=-0.389 p=0.028$, $r=-0.344 p=0.044$, sırasıyla) LL-37 miktarı pozitif korelasyon göstermektedir $(r=0.601 \mathrm{p}=<0.001)$.

Sonuç: Glisemik kontrol salya hBD ve LL-37 konsantrasyonu üzerinde bağımsız bir belirteçtir.

Anahtar kelimeler: Antimikrobiyal peptid, Tip 2 Diabetes Mellitus, Salya, Glisemik Kontrol.

SUMMARY

Aim: The purpose of this study was to evaluate the dentists' knowledge, attitude and behaviour regarding dental trauma in Rize Province.

Materials and Methods: Total of 121 dentists, 73 females and 48 males, were included in this study. A questionnaire consisted of 34 questions and three sections was applied face to face. Personal and professional knowledge and attitudes about dental trauma were evaluated. The association between the dentists at different education level and trauma intervention were analyzed with chi-square test.

Results: Most of general dentists $(48.1 \%)$, postgraduate students $(69.6 \%)$ and specialists $(53.3 \%)$ preferred composite, fiber and ligature wire as splint materials, respectively $(p<0.001)$. There was statistically significant association between dental education level with permanent extrusion ( $p$ $=0.004$ ) and avulsion cases with closed apex in dry environ- 
ment less than 1 hour $(p=0.004)$ and more than 1 hour $(p<0.001)$ outside the mouth, enamel fracture of permanent tooth $(p=0.027)$ and alveolar fracture $(p=0.013)$, primary tooth extrusion $(p=0.013)$, and avulsion injuries $(p=0.017)$. Also, statistically significant relationship was found between dental education level and management of enamel fracture $(p<0.001)$, uncomplicated crown fracture $(p<0.001)$, intrusion $(p=0.018)$ along with alveolar fracture $(p=0.002)$ injuries.

Conclusion: Dentists had sufficient knowledge about dental trauma but avoided intervention in various types of traumatic dental injuries. With in the limits of this study, additional theoretical and practical training on the emergency treatment of cases.may be recommended.

Key words: Dental trauma, avulsion, luxation, dentist, knowledge

\section{GíRiş}

Diabetes Mellitus (DM); Dünya genelinde oldukça yüksek bir prevelans ve insidans oranına sahip metabolik bir hastalıktır. Insülin direnci sonucu gelişen, kronik hiperglisemi ile karakterize olan Tip 2 DM (T2DM), diyabetik vakaların yaklaşık \%90'ını oluşturur. ${ }^{1}$ Glisemik seviyenin uygun olmayan kontrolü tüm vücudu etkilediği gibi periodontal dokuları da etkilemektedir. Periodontitis ve T2DM arasındaki ilişki çift taraflıdır ve periodontitis DM'nin 6. komplikasyonu olarak kabul görmektedir. ${ }^{2}$ T2DM'deki hiperglisemi ve hiperlipidemi inflamatuvar sitokinlerin aktivasyonu ve immün sisteminin fonksiyonu üzerinde etkili olan birkaç mekanizma üzerinde olumsuz etkilere sahiptir. Bunlardan biri de ileri glikolizasyon son ürünleri (AGE) yolağıdır., Hiperglisemi ile doğru orantılı artış gösteren AGE; vücutta serbest olarak veya reseptörlerine (RAGE) bağlanarak doku ve hücrelerin sinyal iletimlerini ve fonksiyonlarını bozmaktadır. ${ }^{5}$ Tüm bunların yanında glisemik kontrol, periodontitisin artan risk ve yıkımı için belirleyici faktördür. ${ }^{6}$ Yapılan bir çalışmada glikolize hemoglobin ( $\mathrm{HbA} 1 \mathrm{c})>\% 9$ olan kontrolsüz T2DM hastalarında ileri periodontal yıkım oranı \%15 iken kontrollü T2DM'lerde bu oran \%9 ve sistemik olarak sağlıklı bireylerde \%4 olarak gösterilmiştir.? Bu da bize T2DM'deki zayıf glisemik kontrolün ciddi periodontal yıkımla ilişkili olduğunu göstermektedir.

Oral epitel, mikrobiyal invazyona karşı periodontal yapıların hem mekanik hem de immün yanıt verilerek korunduğu ilk savunma hattıdır. ${ }^{8}$ Oral epitelden salınan antimikrobiyal peptidler küçük ve katyonik yapılı moleküllerdir. Insan vücudunda 45 farklı antimikrobiyal peptid bulunmaktadır ancak bunlardan insan beta-defensinler (hBD) ve kathelisidinler (LL-37) homeostazın sağlanmasında önemli görevler alırlar. ${ }^{9}$ Esas olarak epitel hücrelerinden salınım gösteren hBD 1-3 ve nötrofil kökenli olan LL-37 gingival epitelde, dişeti oluğu sıvısında (DOS) ve salyada izole edilmiştir.10,11 hBD ve LL-37 multifonksiyonel peptidlerdir. Öncelikle antimikrobiyal fonksiyonları ile öne çıkan bu peptidler, başlangıç ve kazanılmış immün yanıtta da; fagositozu arttırarak, pro-inflamatuvar sitokin salınımını baskılayarak ve kompleman sistemi regüle ederek rol alırlar. Farklı tip immün hücrelere kemoatraktan özellik gösterdikleri ve tüm bu etkilerinin dışında yara iyileşmesini de regüle ederek anjiogenezi arttırdıkları gösterilmiştir. ${ }^{12,13}$ Oral ve periodontal doku ve sIvilarda, T2DM ile antimikrobiyal peptid salınımı arasındaki ilişki halen net değildir ve çelişkili sonuçlar bulunmaktadır. ${ }^{14-17}$ Periodontal yıkım üzerinde direk etkisi gösterilen glisemik kontrolün ve AGE seviyelerinin, oral antimikrobiyal peptid salınımları üzerine etkisi de literatürde çalışılmamış bir konu olarak göze çarpmaktadır. Glisemik kontrolün antimikrobiyal peptid salınımına olası etkisi, T2DM ile periodontitis arasındaki karmaşık ilişkinin açıklanmasında bir paya sahip olabilir.

Çalışmamızda T2DM'li bireylerin glisemik kontrolü, salya antimikrobiyal peptid seviyesini etkiler hipotezi test edilmiştir. Tüm bu bilgiler ışığında, çalışmamızın amacı, T2DM'li bireylerde glisemik kontrol seviyesinin, salya hBD ve LL-37 miktarları üzerine olan etkisini ve salya AGE miktarı ile antimikrobiyal peptidlerin olası korelasyonlarının incelenmesidir.

\section{GEREÇ VE YÖNTEM}

2.1 Çalışma Grupları ve Klinik Değerlendirme : Mevcut çalışma için örnekler toplanmadan önce, gerekli etik izin, Sakarya Üniversitesi Tıp Fakültesi Etik Kurulu tarafından verilmiştir. (Protokol numarası:16214662/050.01.04/37). Çalışmaya katılan bireyler, Sakarya Üniversitesi Diş Hekimliği Fakültesi Periodontoloji A.D. ve Sakarya Üniversitesi Tıp Fakültesi Dahiliye A.D.'ye bağlı diyabet polikliniğine rutin kontrolleri için başvuranlar arasından seçilmiştir. Katılımcıların seçimi ve örnek toplama işlemleri Nisan 2018-Aralık 2018 tarihleri arasında tamamlanmıştır. Toplamda 178 birey çalışmaya dahil edilmiştir. Çalışma grupları ise şu şekilde oluşturulmuştur: 1) Kontrolsüz T2DM+periodontitis: 31 birey, 2) Kontrolsüz T2DM+ periodontal sağlık: 26 birey, 3) Kontrollü T2DM+periodontitis: 31 birey, 4) Kontrollü T2DM+ periodontal sağlık: 31 birey, 5) Sistemik sağlık+ periodontitis: 28 birey, 6) Sistemik sağlık+periodontal sağlık: 27 birey.

Çalışmaya dahil edilen bireyler, detaylıca bilgilendirilmiş ve yazılı onamları alınmıştır. Yaş, cinsiyet, medikal geçmiş, aile geçmişi, medikal ve dental tedavi geçmişleri, sigara ve alkol kullanımı, diyabet süresi, aktif olarak kullanılan antidiyabetik ilaç ve/veya insülin doz ve süreleri ile ilgili bilgiler, yüz yüze soru cevap şeklinde elde edilmiştir. 18 yaşın altında olan, son 6 ayda antibiyotik kullanan, aktif olarak sigara kullanan, periodontal tedavi gören, hamile ve emzirenler, HIV taşıyıcıları ve AIDS hastaları, transplantasyon, genetik, renal ve hepatik hastalık hikayesi olan bireyler çalışma dışı bırakıımıştır.

Bireylerin metabolik değerlendirmesi, T2DM teşhisi ve diyabetin kontrol seviyesi bir dahiliye uzmanı tarafından 
yapılmıştır. (EUA) T2DM teşhisleri Amerikan Diyabet Derneği'nin 2018 rehberliğine bağlı kalınarak yapılmıştır. Buna göre açlık kan şekeri değeri (AKŞ) $\geq 126 \mathrm{mg} / \mathrm{dL}$ (7.0 $\mathrm{mmol} / \mathrm{L}$,açlık: en az 8 saat süre ile kalori alınmaması olarak tanımlanmıştır) ve $\mathrm{HbA} 1 \mathrm{c}$ değeri $\geq 6.5 \%(48 \mathrm{mmol} / \mathrm{mol})$ olan bireylere T2DM teşhisi konulmuştur. Aynı rehbere göre $\mathrm{HbA} 1 \mathrm{c}$ değeri $\geq 8.5 \%$ (70 $\mathrm{mmol} / \mathrm{mol})$ olan bireyler kontrolsüz T2DM olarak tanımlanmıştır.

Bireylerin periodontal durum değerlendirmeleri tek bir uzman (DY) tarafından yapılmıştır. Bu değerlendirmede ağız içindeki tüm dişlerin, plak indeksi $(\mathrm{PI})^{18}$, gingival indeksi $(G I)^{19}$, periodontal sondlama derinliği (PSD) ve klinik ataçman seviyesi (KAS) değerleri periodontal sondun (PW7, Hu-Friedy, IL, ABD) yardımıyla her dişin 6 bölgesinden yapılan manuel ölçümlerle kayıt edilmiştir. Bireylerin alveolar kemik seviyeleri, alınan panoromik görüntüler yardımıyla değerlendirilmiştir (Orthopantomograph OP 100, Sirona Orthophos XG5, NY, ABD). Periodontitis teşhisleri periodontal ve peri-implant hastalık ve durumların 2017 sınıflandırmasına göre yapılmıştır. ${ }^{20}$ Kısaca, katıımcıların sondlamada kanama değerleri $\geq \% 10$ 'nun üzerinde ise ve komşu olmayan 2 'den fazla dişte $P S D \geq 4 \mathrm{~mm}$ olacak şekilde interdental KAS saptanmış ise periodontitis olarak tanımlanmışlardır. Teşhis edilen periodontitis evre ve sınıf sistemine göre derecelendirilmiştir. Periodontitis hastalarının radyolojik kemik kayıpları, kökün orta üçlüsü veya daha derine ilerliyorsa, $K A S>5 \mathrm{~mm}$ ve periodontal nedenle kayıp diş sayısı $<4$ ise, hastalar evre III olarak tanımlanmıştır. Çalışmaya katılan bireylerin önceki periodontal kayıtları bulunmadığından, hastalık derecesi; periodontitisten en çok etkilenen dişin kemik seviyesi ile hastanın yaşının oranı hesaplanarak belirlenmiştir. Buna göre kemik seviyesi/yaş oranı $>1$ ise, sınıf $C$ teşhisi konulmuştur. Bunun haricinde, sigara kullanımı ve diyabet gibi belirli risk faktörlerinin varlığında, sınıf bir seviye daha yükseltilmiştir. Bu tanımlara göre çalışmaya katılan bireylerin \%51'ine (92 kişi) evre 3 sınıf $C$ periodontitis teşhisi konulmuştur ve geri kalan bireyler periodontal olarak sağlıklı olarak tanımlanmıştır.

\subsection{Salya Örneklerinin Toplanması.}

Çalışmadaki salya örnekleri, periodontal ve metabolik muayene öncesinde toplanmıştır. Stimüle olmayan salya toplama tekniği kullanılmışı̧ı. Buna göre bireylerden 5 dakika boyunca $5 \mathrm{~mL}$ 'lik plastik tüplere tükürmeleri istenmiştir. Örnek toplama işlemi sabah saat 8-10 arasında yapılmıştır ve bireylerin bu işlemden en az 1 saat öncesinde yemek yememiş olmasına dikkat edilmiştir. Örnekler toplandıktan sonra santrifüj edilmiş (6000 g, 5 dakika) ve sonrasında analizlere kadar $-80^{\circ} \mathrm{C}$ de saklanmıştır.

2.3 Salyadaki hBD, LL-37 ve AGE Değerlerinin Analizi. Salyadaki hBD-1, -2, -3, LL-37 ve AGE seviyeleri ticari olarak bulunan ELISA kitleri yardımıyla ölçülmüştür.(SinoGeneClon Biotech Co., Ltd, HangZhou, Çin) Tüm ölçümler üretici firmanın önerisi doğrultusunda yapılmıştır. Özetle; $100 \mu 1$ standart veya örnek her bir kuyucuğa pipetlendikten sonra 5 kere yıkama işlemi yapılmıştır. Bu işlemden sonra, $37^{\circ} \mathrm{C}$ 'de 30 dakika boyunca inkübe edilmiştir. Hazırlanmış saptayıcı solüsyon (100 $\mu \mathrm{L})$ kuyucuklara eklendikten sonra $37^{\circ} \mathrm{C}$ 'de 30 dakika boyunca inkübe edilmiştir, sonrasında $100 \mu \mathrm{L}$ kromojen solüsyonu eklenmiş ve $37^{\circ} \mathrm{C}^{\prime} \mathrm{de}$ 15 dakika inkübasyonu yapılmıştır. Son olarak $100 \mu \mathrm{L}$ durdurucu solüsyon eklenmiş ve plakaların 450nm'deki absorbans değerleri cihaz yardımıyla okutulmuştur. (Triturus, Grifols International, S.A., Barcelona, İspanya) Kitlerin minimum ölçme değerleri; hBD-1: 6ng/L, hBD-2: 5ng/L, hBD-3: 2ng/L, LL-37: 1ng/mL ve AGE için 26ng/ml'dir.

\section{4 İstatiksel Değerlendirme}

Çalışmanın primer sonuç değiş̧kenleri antimikrobiyal peptidlerdir (hBD-1, hBD-2, hBD-3 ve LL-37). Bireylerin periodontitise sahip olup olmadıkları sabit tutulduğunda mevcut bulgulara göre sistemik sağlıklı, kontrollü T2DM ve kontrolsüz T2DM grupları arasında antimikrobiyal peptidler yönünden saptanan farklııklar açısından çalışmanın gücü \%67.8 ile \%99.1 arasında değişmekteydi. Post-hoc güç analizinde Tip I hatayı kontrol edebilmek için Bonferroni Düzeltmesi yapılmış ve alfa hatası 0.025 olarak kabul edilmiştir. Post-hoc güç analizleri G*Power 3.0.10. (Franz Faul, Universität Kiel, Kiel, Almanya) paket programında yapılmıştır.

Sürekli sayısal değişkenlerin dağılımının normale yakın dağılıp dağılmadığı Kolmogorov-Smirnov testiyle incelenirken varyansların homojenliği varsayımının sağlanıp sağlanmadığı Levene testiyle araştıııldı. Tanımlayıcı istatistikler sürekli sayısal değişkenler için medyan (çeyrekler arası dağılım genişliği) biçiminde gösterilirken kategorik değişkenler olgu sayısı ve (\%) şeklinde ifade edildi. Sistemik sağlıklı, kontrollü T2DM ve kontrolsüz T2DM grupları içerisinde dişeti sağlıklı ve periodontitisi olanlar arasında sürekli sayısal değişkenler yönünden farkın önemliliği Mann Whitney $U$ testi ile değerlendirilirken kategorik değişkenler süreklilik düzeltmeli Ki-Kare testiyle incelendi. Bonferroni Düzeltmesine göre $p<0.0167$ için sonuçlar istatistiksel olarak anlamlı kabul edildi. Dişeti sağlıklı olan ve periodontitisi olan olgular içerisinde sistemik sağlıkl, kontrollü T2DM ve kontrolsüz T2DM grupları arasında sürekli sayısal değişkenler yönünden farkın önemliliği Kruskal Wallis testiyle incelenirken kategorik değişkenler Pearson'un Ki-Kare testiyle değerlendirildi. Bonferroni Düzeltmesine göre $p<0.025$ için sonuçlar istatistiksel olarak anlamlı kabul edildi. Kruskal Wallis test istatistiği sonuçlarının önemli bulunması halinde Conover'in çoklu karşılaştırma testi kullanılarak farka neden olan durum(lar) tespit edildi. Her bir alt grup içerisinde antimikrobiyal peptidler ile klinik göstegeler, hiperglisemik kontrol göstergeleri ve AGE ölçümleri arasında istatistiksel olarak anlamlı korelasyon olup olmadığı ise Spearman'ın sıra sayıları korelasyon 
testiyle araştırıldı. $\mathrm{p}<0.05$ için sonuçlar istatistiksel olarak anlamlı kabul edildi. Verilerin analizi IBM SPSS Statistics 17.0 (IBM Corporation, Armonk, NY, ABD) paket programında yapıldı. Mevcut çalışmada olası tüm çoklu karşılaştırmalarda Tip I hatayı kontrol edebilmek için Bonferroni Düzeltmesi yapılmıştır.

\section{BULGULAR}

Çalışmaya katılan bireylerin demografik, klinik periodontal ve glisemik kontrol göstergeleri Tablo-1'de verilmiştir.

Tablo 1. Gruplara göre olguların demografik, klinik periodontal ve glisemik kontrol verileri.

\begin{tabular}{|c|c|c|c|c|}
\hline & $\begin{array}{c}\text { Sistemik } \\
\text { sağlıklı }\end{array}$ & $\begin{array}{c}\text { Kontrollü } \\
\text { T2DM }\end{array}$ & $\begin{array}{c}\text { Kontrolsüz } \\
\text { T2DM }\end{array}$ & p-değeri † \\
\hline \multicolumn{5}{|l|}{ Yaş(yII) T } \\
\hline Dişati sağlıkhl & $43.5(27.75)$ & $48.5(16.25)$ & $49.0(18.75)$ & $0.232^{\mathrm{A}}$ \\
\hline Periodontitis & $45.0(17.50)$ & $50.0(16.50)$ & $51.0(16.00)$ & $0.212^{\mathrm{A}}$ \\
\hline p-değeri & 0.684 & 0.742 & 0.608 & \\
\hline \multicolumn{5}{|l|}{ Cinsiyet K } \\
\hline Dişeti sağlıklı & $11(39.3)$ & $15(46.9)$ & $10(38.5)$ & $0.767^{\mathrm{C}}$ \\
\hline Periodontitis & $14(48.3)$ & $16(50.0)$ & $14(45.2)$ & $0.927^{\mathrm{C}}$ \\
\hline p-değeri & 0.677 & $>0.999$ & 0.810 & \\
\hline \multicolumn{5}{|l|}{ PI } \\
\hline Dişeti sağlıklı & $0.45(0.75)$ & $0.50(0.58)$ & $0.43(0.43)$ & 0.290 \\
\hline Periodontitis & $2.50(0.38)$ & $2.53(0.32)$ & $2.50(0.32)$ & 0.938 \\
\hline p-değeri & $<0.001$ & $<0.001$ & $<0.001$ & \\
\hline \multicolumn{5}{|l|}{ PSD (mm) } \\
\hline Dişeti sağlıklı & $2.18(0.68)$ & $2.44(0.66)$ & $2.13(0.39)$ & 0.067 \\
\hline Periodontitis & $5.31(0.59)$ & $5.44(0.33)$ & $5.50(0.63)$ & 0.217 \\
\hline p-değeri & $<0.001$ & $<0.001$ & $<0.001$ & \\
\hline \multicolumn{5}{|l|}{ KAS (mm) } \\
\hline Dişeti sağlıkhl & $2.67(0.82)^{\mathrm{a}}$ & $2.75(0.71)^{\mathbf{b}}$ & $2.16(0.48)^{\mathrm{a}, \mathrm{b}}$ & $<0.001$ \\
\hline Periodontitis & $5.62(0.78)^{\mathrm{a}, \mathrm{c}}$ & $5.98(0.97)^{\mathrm{c}}$ & $6.32(1.11)^{\mathrm{a}}$ & 0.002 \\
\hline p-değeri & $<0.001$ & $<0.001$ & $<0.001$ & \\
\hline \multicolumn{5}{|l|}{ GI } \\
\hline Dişeti sağlıkhl & $0.25(0.28)$ & $0.25(0.31)$ & $0.25(0.19)$ & 0.600 \\
\hline Periodontitis & $2.25(0.37)$ & $2.25(0.36)$ & $2.43(0.25)$ & 0.091 \\
\hline p-değerił & $<0.001$ & $<0.001$ & $<0.001$ & \\
\hline \multicolumn{5}{|l|}{$\mathrm{AKŞ}(\mathrm{mg} / \mathrm{dL})$} \\
\hline Dişeti sağlıkil & $93.5(16.75)^{\mathrm{d}, \mathrm{e}}$ & $142.5(44.50)^{\mathrm{df}}$ & $187.0(104.25)^{\text {eff }}$ & $<0.001$ \\
\hline Periodontitis & $95.0(15.50)^{\mathrm{d}, \mathrm{e}}$ & $128.0(44.75)^{\mathrm{df}}$ & $203.0(75.00)^{e, f}$ & $<0.001$ \\
\hline p-değeri & 0.576 & 0.069 & 0.636 & \\
\hline \multicolumn{5}{|l|}{ HbA1c(\%) } \\
\hline Dişti sağlıkhl & $5.5(0.58)^{\mathrm{d}, \mathrm{e}}$ & $7.2(0.50)^{\mathrm{d} f \mathrm{f}}$ & $9.4(2.15)^{\mathrm{e}, \mathrm{f}}$ & $<0.001$ \\
\hline Periodontitis & $5.4(0.95)^{\mathrm{d}, \mathrm{e}}$ & $7.3(0.67)^{\mathrm{d} f \mathrm{f}}$ & $9.1(1.60)^{\mathrm{e}, \mathrm{f}}$ & $<0.001$ \\
\hline p-değeri & 0.383 & 0.571 & 0.352 & \\
\hline
\end{tabular}

a: Sistemik sağlıklı grup ile kontrolsüz T2DM grubu arasındaki fark istatistikse olarak anlamlı ( $p<0.01)$, b: Kontrollü T2DM grubu ile kontrolsüz T2DM grubu araolarak anlamlı $(\mathrm{p}<0.01)$, b: Kontrollü T2DM grubu ile kontrolsüz T2DM grubu arasındaki fark istatistiksel olarak anlamlı $(p<0.001)$, c: Sistemik sağlıklı grup ile kont-
rollü T2DM grubu arasındaki fark istatistiksel olarak anlamlı ( $p=0.004)$. d: Sistemik rollü T2DM grubu arasındaki fark istatistiksel olarak anlamlı $(p=0.004)$. d: Sistemik
sağlıklı grup ile kontrollü T2DM grubu arasındaki fark istatistiksel olarak anlaml $(p<0.001)$, e: Sistemik sağlıklı grup ile kontrolsüz T2DM grubu arasındaki fark is tatistiksel olarak anlamlı $(p<0.001)$, f: Kontrollü T2DM grubu ile kontrolsüz T2DM grubu arasındaki fark istatistiksel olarak anlamlı $(p<0.01)$.

Buna göre beklenildiği üzere PI, GI, PSD ve KAS değerleri periodontitisli hasta gruplarında periodontal sağlkkı gruplara göre daha yüksek bulunmuştur $(p<0,001)$ T2DM'li bireylerden oluşan gruplarda ortalama T2DM süreleri $6.82 \pm 2.79$ yıldır. Kontrollü T2DM bireylerin \%9,6 (6 birey) , kontrolsüz T2DM bireylerin ise \%87.7 (50 birey) diyabet tedavileri için intramuskular insülin kullanmaktadır, ve gruplar arasındaki bu fark anlamlı bulunmuştur. $(p<0.001)$. Katılımcıların salya antimikrobiyal peptid ve AGE seviyeleri Tablo 2'de sunulmuştur.
Tablo 2. Gruplara göre olguların salya antimikrobiyal peptid ve AGE değerleri.

\begin{tabular}{|c|c|c|c|c|}
\hline & $\begin{array}{c}\text { Sistemik } \\
\text { sa ğllıkıı }\end{array}$ & $\begin{array}{c}\text { Kontrollü } \\
\text { T2DM }\end{array}$ & $\begin{array}{c}\text { Kontrolsüzz } \\
\text { T2DM } \\
\end{array}$ & p-değeri $†$ \\
\hline \multicolumn{5}{|l|}{ hBD-1 } \\
\hline Dişeti sağlıklı & $0.0(5.91)^{\mathrm{a}}$ & $13.0(8.75)^{\mathrm{a}, \mathrm{b}}$ & $3.6(6.55)^{\mathrm{b}}$ & $<0.001$ \\
\hline Periodontitis & $8.8(9.11)^{\mathrm{a}}$ & $0.0(1.37)^{\mathrm{a}, \mathrm{b}}$ & $8.8(10.69)^{\mathrm{b}}$ & $<0.001$ \\
\hline p-değeri $\$$ & $<0.001$ & $<0.001$ & 0.007 & \\
\hline \multicolumn{5}{|l|}{ hBD-2 } \\
\hline Dişeti sağlıklı & $0.0(10.27)$ & $8.9(12.15)^{b}$ & $0.0(3.50)^{\mathrm{b}}$ & 0.004 \\
\hline Periodontitis & $9.5(14.15)^{\mathrm{a}}$ & $0.0(2.59)^{\mathrm{a}, \mathrm{b}}$ & $5.1(7.63)^{\mathrm{b}}$ & $<0.001$ \\
\hline p-değeri $\$$ & 0.062 & $<0.001$ & 0.003 & \\
\hline \multicolumn{5}{|l|}{ hBD-3 } \\
\hline Dişeti sağlıklı & $2.6(9.86)^{\mathrm{c}}$ & $2.8(9.39)^{\mathrm{b}}$ & $0.0(0.12)^{\mathrm{b}, \mathrm{c}}$ & 0.009 \\
\hline Periodontitis & $7.4(8.89)^{\mathrm{a}}$ & $0.0(0.46)^{\mathrm{a}, \mathrm{b}}$ & $3.4(8.92)^{\mathrm{b}}$ & $<0.001$ \\
\hline p-değeri & 0.039 & 0.006 & $<0.001$ & \\
\hline \multicolumn{5}{|l|}{ LL-37 } \\
\hline Dişeti sağlıklı & $0.01(0.96)^{\mathrm{c}}$ & $0.78(1.59)^{\mathrm{b}}$ & $2.10(0.94)^{\mathrm{b} . \mathrm{c}}$ & $<0.001$ \\
\hline Periodontitis & $0.08(1.13)^{\mathrm{a} f}$ & $2.04(1.26)^{\mathrm{ab}}$ & $2.95(1.61)^{\mathrm{bcc}}$ & $<0.001$ \\
\hline p-değeri & 0.648 & $<0.001$ & 0.004 & \\
\hline \multicolumn{5}{|l|}{$\overline{A G E}$} \\
\hline Dişeti sağliklı & $0.0(33.38)^{\mathrm{a}, \mathrm{d}}$ & $109.0(183.70)^{\mathrm{a}, \mathrm{e}}$ & $205.0(273.75)^{\mathrm{d}, \mathrm{e}}$ & $<0.001$ \\
\hline Periodontitis & $30.0(84.10)^{\mathrm{a}, \mathrm{d}}$ & $165.0(254.15)^{\mathrm{a}, \mathrm{e}}$ & $308.0(318.00)^{\mathrm{d}, \mathrm{e}}$ & $<0.001$ \\
\hline p-değeri & 0.076 & 0.029 & 0.145 & \\
\hline
\end{tabular}

a: Sistemik sağlıklı grup ile kontrollü T2DM grubu arasındaki fark istatistiksel olarak anlamlı ( $p<0.001)$, b: Kontrollü T2DM grubu ile kontrolsüz T2DM grubu arasın daki fark istatistiksel olarak anlamlı $(p<0.025)$, c: Sistemik sağlıklı grup ile kontro süz T2DM grubu arasındaki fark istatistiksel olarak anlamlı $(p<0.01)$. d: Sistemi sağlıklı grup ile kontrolsüz T2DM grubu arasındaki fark istatistiksel olarak anlaml $(p<0.001)$, e: Kontrollü T2DM grubu ile kontrolsüz T2DM grubu arasındaki fark istatistiksel olarak anlamlı $(p<0.025)$.

Dişeti sağlıklı bireylerden oluşan grupların salya hBD seviyeleri değerlendirildiğinde; kontrollü T2DM'li gruptaki bireylerin salya hBD-1, hBD-2, hBD-3 değerlerinin kontrolsüz T2DM'li ve sistemik olarak sağlıklı bireylerden oluşan gruplara oranla anlamlı derecede yüksek olduğu tespit edilmiştir. ( $p<0.001, p=0.004, p=0.009$, sırasıyla) Periodontitisli bireylerden oluşan grupların salya hBD seviyeleri incelendiğinde ise; kontrollü T2DM'li grubun hBD-1, hBD-2 ve hBD-3 değerlerinin sistemik sağlıklı ve kontrolsüz T2DM'li gruplara göre anlamlı derecede düşük olduğu tespit edilmiştir. ( $p<0.001, p<0.001, p=0.006$, sırasıyla). Salya LL-37 değerleri incelendiğinde ise; hem dişeti sağlıklı hem de periodontitisli bireylerden oluşan gruplar arasında, kontrolsüz T2DM'li bireylerden oluşan grupların en yüksek değerlere sahip olduğu tespit edilmiştir. $(p<0.001$, $p<0.001$, sırasıyla)

Dişeti sağlıklı gruplar arasında, antimikrobiyal peptidler ile sırasıyla; klinik göstegeler, glisemik kontrol göstergeleri ve AGE değerleri arasında Bonferroni Düzeltmesine göre istatistiksel olarak anlamlı korelasyon saptanmamıştır ( $p>0.05)$. Periodontitisli bireylerden oluşan gruplar arasında; antimikrobiyal peptidler, klinik göstegeler, glisemik kontrol göstergeleri ve AGE değerleri arasındaki korelasyon katsayıları ve önemlilik düzeyleri Tablo 3'de gösterilmiştir. 
Tablo 3. Periodontitisli alt gruplar icerisinde antimikrobiyal peptidler ile klinik göstegeler, hiperglisemik kontrol göstergeleri ve AGE ölçümleri arasındaki korelasyon katsayıları ve önemlilik düzeyleri.

\begin{tabular}{|c|c|c|c|c|c|c|c|c|c|c|c|c|}
\hline & \multicolumn{4}{|c|}{ Sistemik sağlıklı } & \multicolumn{4}{|c|}{ Kontrollü T2DM } & \multicolumn{4}{|c|}{ Kontrolsüz T2DM } \\
\hline & $h B D I$ & $h B D 2$ & $h B D 3$ & $L L-37$ & $h B D I$ & $h B D 2$ & $h B D 3$ & $L L-37$ & $h B D I$ & $h B D 2$ & $h B D 3$ & $\overline{L L L-3}$ \\
\hline \multicolumn{13}{|l|}{$\overline{\text { PI }}$} \\
\hline$r$ & .024 & -.032 & .129 & .081 & -.150 & .016 & -.011 & .146 & .004 & .218 & .084 & .284 \\
\hline$p-\dagger$ & 0.900 & 0.869 & 0.506 & 0.676 & 0.412 & 0.930 & 0.950 & 0.425 & 0.982 & 0.240 & 0.655 & 0.121 \\
\hline \multicolumn{13}{|l|}{ PSD } \\
\hline$r$ & -.051 & .151 & .172 & .147 & -.141 & -.313 & .039 & -.143 & .375 & -.152 & .013 & .010 \\
\hline$p-\dagger$ & 0.795 & 0.433 & 0.371 & 0.446 & 0.441 & 0.081 & 0.830 & 0.437 & 0.038 & 0.414 & 0.946 & 0.95 \\
\hline \multicolumn{13}{|l|}{ KAS } \\
\hline$r$ & .332 & .525 & 304 & .486 & -.003 & -.130 & .260 & -.031 & .215 & -.064 & -.065 & .035 \\
\hline$p-\dagger$ & 0.078 & 0.003 & 0.109 & 0.007 & 0.987 & 0.479 & 0.150 & 0.867 & 0.245 & 0.734 & 0.727 & 0.85 \\
\hline \multicolumn{13}{|l|}{ GI } \\
\hline$r$ & -.071 & 153 & .063 & .186 & -.218 & .105 & -.038 & .030 & .011 & 182 & .025 & -.002 \\
\hline$p-\dagger$ & 0.715 & 0.427 & 0.744 & 0.334 & 0.231 & 0.568 & 0.837 & 0.871 & 0.953 & 0.327 & 0.896 & $0.99:$ \\
\hline \multicolumn{13}{|l|}{ AKŞ } \\
\hline$r$ & -.231 & -.186 & .044 & -.081 & -.079 & -.202 & -.323 & -.213 & -285 & .090 & -.069 & .157 \\
\hline$p-\dagger$ & 0.228 & 0.334 & 0.819 & 0.677 & 0.668 & 0.267 & 0.072 & 0.241 & 0.121 & 0.629 & 0.714 & 0.400 \\
\hline \multicolumn{13}{|c|}{$\overline{\text { HbA1c }}$} \\
\hline$r$ & .306 & .168 & .481 & .092 & -.153 & -.040 & -.232 & .220 & -.262 & .088 & -109 & .054 \\
\hline$p-\dagger$ & 0.106 & 0.384 & 0.008 & 0.633 & 0.402 & 0.829 & 0.200 & 0.226 & 0.155 & 0.640 & 0.559 & 0.778 \\
\hline \multicolumn{13}{|l|}{ AGE } \\
\hline$r$ & .174 & .156 & .369 & .362 & -.411 & -389 & -344 & .601 & .244 & .312 & .389 & . 411 \\
\hline$p-\dagger$ & 0.367 & 0.418 & 0.049 & 0.054 & 0.020 & 0.028 & 0.044 & $<0.001$ & 0.186 & 0.088 & 0.030 & 0.022 \\
\hline
\end{tabular}

† Spearman'ın sıra sayıları korelasyon testi, Bonferroni Düzeltmesine göre $\mathrm{p}<0.05$ için sonuçlar istatistiksel olarak anlamlı kabul edildi.

Buna göre; kontrollü T2DM'li bireylerin salya hBD-1, -2, -3 değerleri salya AGE konsantrasyonu ile negatif korelasyon gösterirken $(r=-0.411 p=0.020, r=-0.389 p=0.028$, $r=-0.344 p=0.044$, sırasıyla) LL-37 ile pozitif korelasyon göstermektedir $(r=0.601 \quad p=<0.001)$. Kontrolsüz T2DM'li bireylerde ise salya hBD-3 ve LL-37 değerleri ile salya AGE konsantrasyonu arasında pozitif korelasyon saptanmıştır. $(r=0.389 p=0.030, r=0.411 p=0.022$, sırasılyla $)$

\section{TARTIŞMA}

Bilgilerimiz dahilinde mevcut çalışma, T2DM'deki glisemik kontrolün salya antimikrobiyal peptid konsantrasyonu üzerine olan etkisini inceleyen ilk çalışmadır. Bulgularımıza göre glisemik kontrol seviyesi salya antimikrobiyal peptid seviyesini belirleyen önemli bir faktör olarak tespit edilmiştir.

T2DM, tedavi ve takip edilmediğinde vücutta oldukça ciddi komplikasyonlara neden olan mteabolik bir hastalıktır. ${ }^{2}$ Çalışmamızda T2DM teşhisi ve kontrol seviyesinin belirlenmesi için AKŞ ve HbA1c değerlerleri kullanılmıştır. $\mathrm{HbA1c}$ hastanın son 3 aylık ortalama kan şeker değerini gösteren ve T2DM takibi için güvenilir bir göstergedir.' 2018 Amerikan Diabet Derneği'nin yayınladığı rehberliğe göre HbA1c değeri >\%8.5 üzerinde olan bireyler kontrolsüz T2DM olarak tanımlanmışlardır.' Bu bilgi ışığında çalışma gruplarımızdaki bireylerin diabetik kontrol seviyeleri $\mathrm{HbA1c}$ değerleri üzerinden tanımlanmıştır. Çalışmamızın kesitsel dizaynından dolayı bireylerin anlık HbA1c, AKŞ ve salya antimikrobiyal peptid seviyesi ölçümleri yapılabilmiştir ve katılımcıların salya peptid seviyelerinin glisemik seviye değişimleri ile olası etkileşimleri takip edilememiştir, bu durum çalışmamızın limitasyonlarından biri olarak tanımlanabilir.

Sonuçlarımıza göre sistemik sağlıklı periodontitisli bireylerin salya hBD-1 konsantrasyonları, sistemik ve periodontal olarak sağlıklı bireylere göre anlamlı derecede düşük bulunmuştur. Bunun dışında diğer antimikrobiyal peptid seviyelerine bakıldığında periodontitisli bireylerde bir artış eğilimi gözlenmesine rağmen aradaki sonuç istatiksel olarak anlamlı bulunmamıştır. Literatürde periodontitisli bireylerin oral Sıvı ve dokularındaki antimikrobiyal peptid seviyeleri ile ilgili yapılmış çalışmalarda farklı sonuçlar bulunmaktadır. ${ }^{14,21-23}$ Antimikrobiyal peptidlerin protein ve RNA ekspresyon profillerini inceleyen çalışmalara bakıldığında $\operatorname{artan}^{23}$, sabit ${ }^{14,21}$ veya azalan ${ }^{22}$ yanıt tespit eden çalışmalar bulunmaktadır. Farklı sonuçların sebebi olarak, enfeksiyonun hBD ekspresyonunu arttırması ancak inflame dişeti dokusundaki epitel bütünlüğü ve yapısı bozulduğu için de antimikrobiyal peptid salınımının azalabileceği, bunlara ek olarak da konak veya bakteri kaynaklı artan proteolitik aktivitenin antimikrobiyal peptid seviyesini etkileyebileceği ileri sürülebilir. ${ }^{13,24}$ Bununla beraber, çalışılan biyolojik materyallerin farklılığı, periodontitis teşhisinde ve şiddetindeki farklılıklar sebebiyle literatürdeki çalışmalarla mevcut çalışmanın direk karşılaştırmasını yapmak uygun değildir.

Çalışmamızda, salya LL-37 konsantrasyonlarının; hem dişeti sağlıklı hem de periodontitisli bireylerde, kontrolsüz T2DM'li bireylerden oluşan gruplarda en yüksek olduğu tespit edilmiştir. Literatür incelendiğinde T2DM'nin LL-37 miktarına ilişkin etkisiyle ilgili sınırlı bilgi mevcuttur ve bu çalışmalar farklı doku ve hücre tipleri üzerinde gerçekleştirilmiştir. ${ }^{14,25,26}$ Mevcut çalışmada elde ettiğimiz veriler, gingival doku örnekleri üzerinde yapılan bir diğer çalışma ile tutarlılık göstermektedir. ${ }^{14}$ Bu artışa sebep olarak, literatürde ilk defa çalışmamızda göstermiş olduğumuz, salya AGE miktarı ile LL-37 arasındaki pozitif korelasyon rol oynamış olabilir ancak bu artıştaki sinyal mekanızmalarının rolü ileri çalışmalarla incelenmelidir. İmmün sistemde görev alan LL-37 miktarındaki artışa rağmen T2DM hastaları periodontal enfeksiyonlara karşı daha yatkındırlar. Buna etken olarak LL-37'nin yüksek konsantrasyonlarında konak hücrelerine karşı sitotoksik etkiler göstermesi ileri sürülebilir. ${ }^{27}$

Mevcut çalışmamızda periodontitisli bireyler incelendiğinde; salya hBD-1, -2 ve -3 miktarları kontrollü T2DM hastalarında en düşük miktarda tespit edilmiştir ve bu grup hastalarda salya hBD miktarı ile AGE arasında negatif korelasyon tespit edilmiştir. Kontrolsüz T2DM ve sistemik sağlıklı bireylerden oluşan gruplar arasında ise anlamlı fark görülmemiştir. Konuyla ilgili çalışmalar incelendiğinde Lan ve ark. insan keratinosit hücreleri üzerinde yaptıkları çalışmada hiperglisemik ortamın mRNA ve protein seviyesinde hBD-3 miktarını azalttığını göstermişlerdir..17 Başka bir in-vitro çalışma ise, artan AGE miktarının P38 mitojen-aktive protein kinaz sinyal yolağını inhibe ederek hBD miktarının azaldığını savunmuştur ${ }^{28}$, bu bulgular mevcut çalışmamızı destekler niteliktedir. Çalışmamızda gösterilen kontrolsüz T2DM bireylerde gözlenen artmış salya hBD konsantrasyonu farklı mekanizmalarla açıkla- 
nabilir. İlk olarak; kontrolsüz T2DM'li bireylerde görülen aşırı AGE miktarı ile inflamatuvar sitokinler arasındaki pozitif ilişki daha önce gösterilmiştir ${ }^{29}$ ve inflamasyonun da hBD miktarını artırığı bilinmektedir ${ }^{9}$ ancak artan bu hBD'lerin aktivasyonları ve fonksiyonları ileri çalışmalarla açıklanmalıdır. İkinci etken olarak da hastaların diyabet tedavisine bağlı olarak kullandığı ilaçlar ileri sürülebilir, T2DM tedavisinde ilk seçenek olarak oral anti-diyabetik ilaçlar tercih edilmektedir ancak glisemik göstergeler artı̆ğında insülin tedavisine başlanmaktadır. ${ }^{30}$ Çalışmamızda kontrolsüz T2DM grubunda insülin kullanım oranı anlamlı derecede yüksektir. Literatürde insülinin in-vitro ortamda keratinosit hücrelerindeki hBD-1 salınımını arttırdığı gösterilmiştir ${ }^{31}$ ancak bu artışın altındaki mekanizma net değildir ve incelenmelidir. Gingival doku ve DOS üzerinde yapılan bazı çalışmalarda da, T2DM'li bireylerde artan hBD miktarı gösterilmiştir ancak çalışan materyaldeki farklıık ve çalışmaya dahil edilen bireylerin T2DM kontrol seviyeleri göz önüne alındığında mevcut çalışma ile bunları karşılaştııırken dikkatli davranıımalıdır. ${ }^{14,16}$

\section{SONUÇLAR}

Çalışmamızın limitleri dahilinde, salya hBD ve LL-37 seviyeleri üzerinde hiperglisemi önemli bir belirteçtir. Gelecek çalışmalarla bu değişim altında yatan mekanizma ve hastaların diyabetik tedavilerinin olası etkileri incelenmelidir.

\section{KAYNAKLAR}

1. Classification and Diagnosis of Diabetes: Standards of Medical Care in Diabetes-2018. American Diabetes Association. Diabetes Care 2018; 41: 13-27.

2. Casanova L, Hughes FJ, Preshaw PM. Diabetes and periodontal disease: a two-way relationship. Br Dent $\mathrm{J}$ 2014; 217: 433-437.

3. Byun K, Yoo Y, Son M, Lee J, Jeong GB et al. Advanced glycation end-products produced systemically and by macrophages: A common contributor to inflammation and degenerative diseases. Pharmacol Ther 2017; 177: 44-55.

4. Taylor JJ, Preshaw PM, Lalla E. A review of the evidence for pathogenic mechanisms that may link periodontitis and diabetes. J Periodontol 2013; 84: 113-134.

5. Piperi C, Goumenos A, Adamopoulos C, Papavassiliou AG. AGE/RAGE signalling regulation by miRNAs: associations with diabetic complications and therapeutic potential. Int J Biochem Cell Biol 2015; 60: 197-201.

6. Kocher T, König J, Borgnakke WS, Pink C, Meisel P. Periodontal complications of hyperglycemia/diabetes mellitus: Epidemiologic complexity and clinical challenge. Periodontol 2000 2018; 78: 59-97.

7. Tsai C, Hayes C, Taylor GW. Glycemic control of type 2 diabetes and severe periodontal disease in the US adult population. Community Dent Oral Epidemiol 2002; 30: 182-192.

8. Groeger SE, Meyle J. Epithelial barrier and oral bacteri- al infection. Periodontol 2000 2015; 69: 46-67.

9. Gupta S, Bhatia G, Sharma A, Saxena S. Host defense peptides: An insight into the antimicrobial world. J Oral Maxillofac Pathol 2018; 22: 239-244.

10. Gomes Pde S, Fernandes MH. Defensins in the oral cavity: distribution and biological role. J Oral Pathol Med 2010; 39: 1-9.

11. Güncü GN, Yilmaz D, Könönen E, Gürsoy UK. Salivary Antimicrobial Peptides in Early Detection of Periodontitis. Front Cell Infect Microbiol 2015; 24: 5-9.

12. Yang $D$, Liu $Z H$, Tewary $P$, Chen $Q$, de la Rosa $G$ et al. Defensin participation in innate and adaptive immunity. Curr Pharm Des 2007; 13: 3131-3139.

13. Gursoy UK, Könönen E. Understanding the roles of gingival beta-defensins. J Oral Microbiol 2012; 4.

14. Yılmaz $D$, Güncü GN, Könönen $E$, Barış $E$, Çağlayan $F$ et al. Overexpressions of hBD-2, hBD-3, and hCAP18/LL37 in Gingiva of Diabetics with Periodontitis. Immunobiol 2015; 220: 1219-1226.

15. Yilmaz D, Caglayan F, Buber E, Könönen E, Aksoy $Y$ et al. Gingival crevicular fluid levels of human beta-defensin-1 in type 2 diabetes mellitus and periodontitis. Clin Oral Investig 2018; 22: 2135-2140.

16. Ertugrul AS, Dikilitas A, Sahin H, Alpaslan N, Bozoglan A et al. Gingival crevicular fluid levels of human beta-defensins 1 and 3 in subjects with periodontitis and/or type 2 diabetes mellitus: a cross-sectional study. J Periodontal Res 2013; 48: 475-482.

17. Lan CC, Wu CS, Huang SM, Kuo HY, Wu IH et al. High-glucose environment reduces human $\beta$-defensin-2 expression in human keratinocytes: implications for poor diabetic wound healing. $\mathrm{Br} \mathrm{J}$ Dermatol 2012; 166: 12211229.

18. Silness, J, Löe H. Periodontal disease in pregnancy II. correlation between oral hygiene and periodontal condition. Acta Odontol. Scand 1964; 22: 121-135.

19. Löe H, Silness J. Periodontal disease in pregnancy. I. prevalence and severity. Acta Odontol. Scand 1963; 21: 533-551.

20. Papapanou PN, Sanz M, Buduneli N, Dietrich T, Feres $M$ et al. Periodontitis: Consensus report of workgroup 2 of the 2017 World Workshop on the Classification of Periodontal and Peri-Implant Diseases and Conditions. J Periodontol 2018; 89: 173-182.

21. Dommisch H, Skora P, Hirschfeld J, Olk G, Hildebrandt $L$ et al. The guardians of the periodontium-sequential and differential expression of antimicrobial peptides during gingival inflammation. Results from in vivo and in vitro studies. J Clin Periodontol 2019; 46: 276-285.

22. Offenbacher S, Barros SP, Paquette DW, Winston JL, Biesbrock AR et al. Gingival transcriptome patterns during induction and resolution of experimental gingivitis in humans. J Periodontol 2009; 80: 1963-1982. 
23. Pereira AL, Franco GC, Cortelli SC, Aquino DR, Costa FO et al. Influence of periodontal status and periodontopathogens on levels of oral human $\beta$-defensin- 2 in saliva. J Periodontol 2013; 84: 1445-1453.

24. Li S, Schmalz G, Schmidt J, Krause F, Haak R, et al. Antimicrobial peptides as a possible interlink between periodontal diseases and its risk factors: A systematic review. J Periodontal Res 2018; 53: 145-155.

25. Montoya-Rosales A, Castro-Garcia P, Torres-Juarez F, Enciso-Moreno JA, Rivas-Santiago B. Glucose levels affect LL-37 expression in monocyte-derived macrophages altering the Mycobacterium tuberculosis intracellular growth control. Microb Pathog 2016; 97: 148-153.

26. Rivas-Santiago B, Trujillo V, Montoya A, Gonzalez-Curiel I, Castañeda-Delgado $\mathrm{J}$ et al. Expression of antimicrobial peptides in diabetic foot ulcer. Dermatol Sci 2012; 65: 19-26.

27. Svensson $D$, Wilk $L$, Mörgelin $M$, Herwald $H$, Nilsson BO. LL-37-induced host cell cytotoxicity depends on cellular expression of the globular C1q receptor (p33). Biochem J 2016; 473: 87-98.

28. Yeh $\mathrm{CH}$, Sturgis $L$, Haidacher J, Zhang $X N$, Sherwood SJ et al. Requirement for p38 and p44/p42 mitogen-activated protein kinases in RAGE-mediated nuclear factor-kappaB transcriptional activation and cytokine secretion. Diabetes 2001; 50: 1495-1504.

29. Hu $H$, Jiang $H$, Ren $H$, Hu $X$, Wang $X$ et al. AGEs and chronic subclinical inflammation in diabetes: disorders of immune system. Diabetes Metab Res Rev 2015; 31: 127137.

30. Bloomgarden ZT, Handelsman Y. Approaches to treatment 2:Comparison of American Association of Clinical Endocrinologists (AACE) and American Diabetes Association (ADA) type 2 diabetes treatment guidelines. J Diabetes 2016; 8: 4-6.

31. Barnea M, Madar Z, Froy O. Glucose and insulin are needed for optimal defensin expression in human cell lines. Biochem Biophys Res Commun 2008; 367: 452-456. 